\title{
NOTES ON THE HABITS AND EARLIER STAGES OF
} CRYPTOPHASA UNIPUNCTATA, DON.

By Henry Edwards.

(Communicated by A. Sidney Olliff.)

One of the most singular instances of the change of habits in a species of Lepidoptera that has come under my notice is to be found in that of the insect referred to in the present article. As far back as 1858, I was fully acquainted with the species, and raised a considerable number to the imago state. It was then only to be found on the black wattle, Acacia decurrens, the larva burrowing into the stems and younger branches, but, as far as my observations went, never attacking the trunk or the larger arms of the tree. It was not unusual to find specimens in the very early morning, (i.e., at 5 or 6 a.m.) at rest upon the leaves of the wattle, but later in the day they hid themselves from the sunlight, and were very rarely met with. On my return to the colonies, during the past summer, I was led to observe that many fruit trees in the garden of the Hon. George Coppin, at Richmond, near Melbourne, had been attacked by some pest, and were rapidly approaching destruction. Close investigation displayed the fact that some burrows had been made in the trees, somewhat similar to those of the Cossida, the entrance to these burrows being artfully concealed by a small cap of fragments of wood and bark, so closely cemented together as to appear like a portion of the bark itself. Upon cutting down one of the diseased branches, and splitting it open, I found that the burrow passed almost at right angles to the very heart of the branch, and thence downward for a space of 15 or 16 inches. At the bottom of this burrow I found a full-grown larva, which, when disturbed, wriggled itself about with very rapid movements, crawling up and down its burrow with surprising quickness. Below the home of the first insect noted was another burrow of 12 inches in depth, and in this 
I found a healthy pupa, equally with the larva disinclined to leave its resting place. Wherever throughout the garden a dead branch was to be seen, it was always found to contain one or more of these insects in either the larva or pupa state, and their number can be guessed at when I say that not less than thirty trees had been more or less attacked by this destructive species. Those most affected were cherry, plum, apricot, nectarine, and peach, but I found also one pear and one quince tree each containing a larva, and it is possible that in the course of a short time, the apple trees may also suffer. As in the Cossida, Egeriada, and other internal feeders, the pupa, when near the final change, works its way to the mouth of the burrow, and the moth, as it emerges, softens the cover of chips with which the entrance is closed, and so makes its escape. The pupa does not protrude, as is the case in the above-named families, but remains a little distance within the opening. The moths emerge from the pupa about 6 or 7 p.m., and may then be found adhering to the branches, often in copula. They are easily attracted by light, and no less than eighteen fine specimens were taken in one evening at a lamp placed rather high in the house. They are exceedingly delicate insects, and are easily killed in the cyanide bottle, usually dying in from 20 to 25 seconds. Great care has to be exercised in handling them, as the fine silverywhite scales are very readily removed. The genus appears to be distinctly Tortricid, and has nothing in common (save its method of burrowing) with the Cossida, in which it has been placed by some authors.

The following descriptions apply to the stages in which I was enabled to observe it :-

Larva.-Full grown. Tortricid in form, the head tapering in front, and truncate, pitchy, rugose, with slight dorsal channel. Mouth parts ample. Upper side of body, except the 2nd segment, which is pitchy, dull pale chocolate-brown. Under side sordid white. Spiracles pale pitchy, as are also the thoracic feet. On the dorsum is a series of double ovate shining spots, placed transversely, a little darker than the ground colour. These spots differ 
in intensity in various individuals. There are a few short hairs upon all the segments, and especially about the head and anal extremity. Length $35 \mathrm{~mm}$.

Pupa.-Cylindrical, rounded in front, and tapering suddenly posteriorly. Colour bright chestnut-brown in life, changing to pitchy. The head, thorax, and wing cases darker than the rest. Surface very much roughened, the head and thorax being covered with transversely raised waved ridges. The abdominal segments are also wrinkled, but less rugosely. Wing cases broad, smooth, glossy, those of the antennæ being strongly defined. Anal segment rounded. Cremaster short, bifurcate. Length $23 \mathrm{~mm}$. Width across wing cases $8 \mathrm{~mm}$.

This pretty species must now be included among the most injurious insects of Australia, but as it is eagerly sought by collectors, its numbers may be easily kept in check. I have seen it in two collections marked Morgia gigantella, Walk.

ON S P E CIES-M A K I N G. By W. H. Miskin, F.E.S. 


\section{$2 \mathrm{BHL}$ Biodiversity Heritage Library}

Edwards, Henry. 1890. "Notes on the habits and earlier stages of Cryptophasa unipunctata, Don." Proceedings of the Linnean Society of New South Wales 5, 300-302. https://doi.org/10.5962/bhl.part.18640.

View This Item Online: https://www.biodiversitylibrary.org/item/22899

DOI: https://doi.org/10.5962/bhl.part.18640

Permalink: https://www.biodiversitylibrary.org/partpdf/18640

\section{Holding Institution}

MBLWHOI Library

\section{Sponsored by}

MBLWHOI Library

\section{Copyright \& Reuse}

Copyright Status: NOT_IN_COPYRIGHT

This document was created from content at the Biodiversity Heritage Library, the world's largest open access digital library for biodiversity literature and archives. Visit BHL at https://www.biodiversitylibrary.org. 